\title{
Factorial Analysis of the Critical Success Factors of Continuous Improvement (CI) Techniques in the Companies from Sohar Industrial Estate, Oman
}

Samiya Abdullah Al-Qayoudhi ${ }^{1}$, Shanmuga Pria ${ }^{2}$, Venkata Vara Prasad ${ }^{3}$

University of Technology \& Applied Sciences, Shinas, Oman

Email: $\underline{1}$ Rawan6660@yahoo.com, 르‥pria@gmail.com, ${ }^{3}$ Venkata.prasad@ shct.edu.om

Citation: Al-Qayoudhi, S.A., Pria, S. \& Prasad, V.V. (2021). Factorial Analysis of the Critical Success Factors of Continous Improvement (CI) Techniques in the Companies from Sohar Industrial Estate, Oman. International Journal of Research in Entrepreneurship \& Business Studies, 2(4), 1- 46.

https://doi.org/10.47259/ijrebs.241

Received on $24^{\text {th }}$ Aug. 2021

Revised on $15^{\text {th }}$ Sep. 2021

Published on $4^{\text {th }}$ Oct. 2021

Copyright: () 2021 by the authors. Licensee Global Scientific Publications, Oman.

\section{Publishers Note:}

This work is licensed under a $\underline{\text { Creative }}$ Commons Attribution-ShareAlike 4.0 International License. This is an open-access journal and the articles published in this journal are distributed under the terms of CC-BY-SA.

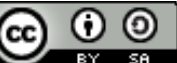

\section{Abstract}

Purpose: The research objectives were to analyze the role of continuous improvement (CI) techniques in manufacturing in Oman in the CI process and to investigate the crucial factors of CI and the application techniques of CI that have been implemented by the manufacturing companies during the $\mathrm{CI}$ process.

Design/methodology/approach: A survey questionnaire was developed with the baseline of CI practices used by manufacturing companies in Oman and a convenient sampling method was used to collect the data. 146 filled-in questionnaires were collected from 75 manufacturing units out of the entire Public Establishment database. The data was tabulated, compiled. The robustness was tested along with the ranking tests and the factor analysis using SPSS and AMOS.

Findings: The results reveal that the Omani manufacturing companies using structured CI programs had lesser product recalls, leading to increased overall sales, decrease in processing time. Further, it is also revealed that the CI culture and Employee Performance Measurement and Review are instrumental in translating into company savings.

Research limitations/implications: This research was limited to the Sohar Industrial estate only. As there are nine industrial estates in Oman, the research can be undertaken to study the CI practices adoption in all the other industrial estates as well.

Social Implications: Countries from all over the world are facing numerous challenges due to COVID-19. The paper will help the manufacturing companies in decision making towards the process improvement.

Originality / Value: There were not many studies on continuous improvement practices within the Omani manufacturing industry and this paper examines the status of CI implementation in manufacturing companies in Oman.

Keywords: Continuous Improvement Practices, Manufacturing Industry, Critical Success Factors, Company Success Factors, Sultanate of Oman.

\section{Introduction}

A budget is a planning tool used for allocating resources of an organization to several different functions (Abdallah, 2018). A budget is a method for controlling the financial performances and ensuring the achievement of the administrative and financial goals of the company (Etale and Idumesaro, 2019). One of the most important techniques used for planning and controlling jobs within an organization is budgeting and budgetary control.

CI can be defined as a culture meant for sustained improvement aiming at removing the wastage in the entire organizational setup and the processes. It is also defined as a group of systematic processes - well organized but with constant changes, involving all the concerned within the organization towards productivity, quality, with effectiveness (Jurburg et al., 2017). 
Organizations need CI, the advancement of CI technologies and the introduction of CI in the organizations has led to improvement in quality, production, and reduction in wastage. A few of such most popular CI technologies are Balanced Scorecard, Lean Manufacturing, Lean Six Sigma/Six Sigma (Haddas et al., 2014). The popularity of CI tools in general and Kaizen in particular also has been caused by increasing the effective usage of such applications and the related tools (Glover et al., 2014). The organizations can remain competitive in a market by implementing CI to fulfill the customer demands in effective ways using the applied leading to improved organizational performance (Aleu \& Van Aken, 2016; Galli, 2018).

The global market environment has intensified the competitiveness of supply and uncertainty in consumer demand. Global competitiveness has forced all businesses simply its processes to gain more profits through adopting the latest technologies. These changes have made permanent traces in the manufacturing industry. To face the demands faced by today's global market, manufacturing companies must strengthen production and relationships with vendors, as well as implement performance enhancement programs in all facets of their operations (Singh and Singh, 2017). Further, to stay competitive in this ever-changing world, businesses must figure out innovative solutions that enable them to be both competitive and flexible at the same time, helping them to adapt quickly to new demands. Total quality management (TQM) is an approach that aims at achieving customer satisfaction, and the organizational culture (Bakator et al., 2018). TQM is considered the most important tool used to accomplish efficiency and quality is the power required to attain the efficiency for CI (Al-Qayoudhi et al., 2017).

Organizations must determine the extent of activities that are critical to them. They must concentrate on the most critical factors rather than mismanaging resources on less important or non-essential factors. As a result, an effort has been made to evaluate the success factors of continuous improvement and determine the direct and indirect interaction between these factors. The manufacturing sector of Oman can have a steady growth depending on the improvement of the competitive status of the net exports. This is indeed an active process. In Oman, the implementation of such trade policies is done by the Oman Ministry of Commerce and Industry.

Oman's economy is experiencing a tough time as the oil prices drop on one hand whereas the COVID-19 pandemic on the other. The inflation rate and prices movement were reported to be very high during March 2021, i.e. 3.4 percent (compared to 1 percent reported in 2020). In this situation, it is becoming obligatory for such companies involved in production to minimize the cost of production whereas augmenting productivity. During 2018, the performance indicators readiness for future production, drivers of production ranked 45 out of 100 in 2018, while the target for 2030 to be set up for 2030, in the top twenty countries (Oman Observer, 2020; World Economic Forum, 2018).

\section{Statement of Research Problem}

There is no detailed study carried out on the continuous improvement practices prevailing in the manufacturing industry of Oman. This paper throws light on the status of the CI implementation in manufacturing companies of Oman. This paper also analyses the details such as the introduction of CI, the tools and the Critical Success Factors (CSF) adopted, to what extent CI practices were implemented, and the benefits reaped through such introduction, etc. Thus, the prime objective of the study was to 'investigate the best applications/techniques of continuous improvements among manufacturing companies in Oman'.

\section{Research Questions}

The study focuses on the following questions:

1. How do the CI techniques adopted in manufacturing companies in Oman help in the continuous improvement process?

2. What are the best crucial factors of CI and the application techniques of CI that have been implemented by the manufacturing companies during the CI process?

\section{Research Objectives}

In line with the above research questions, the following research objectives were defined:

1. To analyze the role of CI techniques in manufacturing in Oman in the CI process. 
2. To investigate the crucial factors of $\mathrm{CI}$ and the application techniques of $\mathrm{CI}$ that have been implemented by the manufacturing companies during the CI process.

\section{Literature Review and Hypothesis Formulation}

Continuous Improvement (CI) is powerful to boost efficiency, and qualitative performance and Maletič et al. (2012) confirmed the impact of CI on maintenance performance.

During the past two decades, manufacturing businesses have been rapidly changing and operating in a highly competitive market, giving importance to lean thinking. Lean thinking leads the way to define the value of the actions in the best way, applying these activities continues to be effective. Lean thinking shows the way to achieve greater efficiency in less time with less equipment, less manpower, and respond to customer requests more (Womack and Jones, 2017). Lean production is defined as the systems that provide enterprises with a competitive advantage and aim to achieve efficient production by reducing unnecessary resources usage (Adalı \& Isik, 2017).

The lean manufacturing process is a major initiative to eliminate wastages from manufacturing operations but it is not easier to introduce in the manufacturing sector as several stakeholders with conflicting interests are involved (Salonitis \& Tsinopoulos, 2016). Lean manufacturing is a continuous process that influences both the process and people but the main challenge is in the implementation as utmost guidance is required during the change journey process. successful lean transformation depends on the guidance of the top management and the leadership, and other factors called critical success factors (Alefari, et al., 2017). The lean approach not only involves a change of process but also the creation of a new culture consisting of management strategies applicable to the entire organization (Improta et al., 2018).

\section{Visual Management (VM)}

Visual Management (VM) is apprehensive of the practices to draw information about the production part of the companies as it has become an essential component of the lean management practice for CI and is gaining attention from the stakeholders (Jaca et al., 2014). According to Kurpjuweit, et al. (2019) VM works only when all the managerial hierarchy gets involved and the top management implements VM, failing which there will be a break in implementation.

\section{Employee Engagement (EE)}

Employee Engagement (EE) is a crucial factor in the successful implementation of any new dynamic changes in an organization's performance (Weerasooriyan, et al., 2017). Employee engagement refers to the commitment and drives to go beyond the call of duty towards the organization's goals, whereas employee satisfaction refers to contentment (Madan \& Srivastava, 2015). In other words, Employee engagement is an employee's willingness and ability to contribute to company success by freely giving the extra effort on an ongoing basis. It represents the extent to which employees put discretionary effort into their work (Ghuman, 2016).

Leadership (Lea)

Leadership acts as the foundation based on which the employee engagement employees in CI initiatives purely lies. It is one of the critical factors which links the management and the employees towards the introduction of the lean process (Dombrowski \& Mielke, 2013). Senior management commitment is a vital factor, in defining a clear vision towards acquiring sufficient finance, and strategic leadership. Although the transformation of the lean process is required at the production unit, senior management takes the lead of such transformation as the management commitment and support impact such initiatives (Alefari, et al., 2017).

\section{Risk Management (RM)}

The Centre of any organization's strategic management is risk management. RM is the process through which organizations systematically identify risks associated with their activities to achieve the goal of achieving ongoing benefits in each activity and the light of all activities (Karami et al., 2020). Risk Management (RM) plays a vital role in eliminating the negative impact if any, within the organization as there are various type of risks emerges (Fadzil et al., 2017). RM is a structured strategy used by industries to minimize the probability of unexpected major risks from reducing profits as it entails optimizing the likelihood and implications of good outcomes thus mitigating consequences of negative events to project goals (Ferede et al., 2021). Risk Management can be achieved effectively, only if the risks are identified well and classified correctly (Ahmed, 2018). 


\section{Hypotheses}

After going through the review of literature, the following hypothesis was derived:

1. (a) Implementation of Visual Management (VM) practices have a significant influence on the company's savings.

(b) Implementation of Employee Engagement (EE) practices has a significant influence on the company's savings.

(c) Implementation of will has Leadership (Lea) practices have a significant positive influence on the company's savings.

(d) Implementation of Risk Management practices has a significant positive influence on the company's savings.

\section{Research Model}

From the above discussion, the proposed research model was derived as shown in Figure 1 and used in the study. The model proposed by Al-Qayoudhi et al. (2021) for the continuous improvement practices was used which include visual management, employee engagement, risk management, and leadership practices, to predict the company's savings. Hence, the model uses the company's savings as the final dependent variable. Also, the constructs and the related are shown in Table 1.

Table 1 Constructs

\begin{tabular}{|r|l|l|}
\hline$\#$ & \multicolumn{1}{|c|}{ Variables } & \multicolumn{1}{c|}{ References } \\
\hline 1 & Visual Management (VM) & Jaca et al. (2014), Kurpjuweit, et al. (2019) \\
\hline 2 & $\begin{array}{l}\text { Employee } \\
\text { Engagement (EE) }\end{array}$ & $\begin{array}{l}\text { Weerasooriyan, et al. (2017), Madan \& } \\
\text { Srivastava, (2015), Ghuman, (2016) }\end{array}$ \\
\hline 3 & Leadership (Lea) & $\begin{array}{l}\text { Dombrowski \& Mielke, (2013); Alefari, et } \\
\text { al.,2017 }\end{array}$ \\
\hline 4 & Risk Management (RM) & $\begin{array}{l}\text { Fadzil et al., (2017), Ferede et al. (2021), } \\
\text { Ahmed, (2018), Karami et al. (2020) }\end{array}$ \\
\hline
\end{tabular}

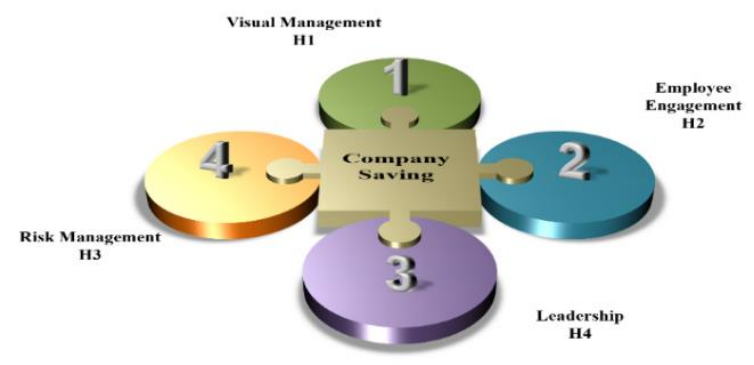

Figure 1 The Research Model Diagram

\section{Research methodology}

The above-mentioned instruments were adopted contextualizing to Omani manufacturing industries and were used in this study. The survey questionnaire was developed with the baseline of CI practices used by manufacturing companies in Oman. Other than the demographic information and company success factors, the questionnaire had statements related to the experience of CI tools and techniques by the manufacturing companies. Twenty Critical Success Factors (CSFs) identified through the review literature were used to obtain the responses. They were as follows:
1. Management support lead to CI
2. Detect the deviations from the standards
6. Top management supports employees
3. Distribution of responsibilities
4. Best solution
5. Flow of information
7. Professional training
8. Spirit and cooperation
9. Meaningful work
10. Creativity 

11. Kaizen team leader
12. The change journey
13. Value to the customers
14. Effective communication
15. Gemba commitment
16. Effective RM team

17. Reliability and profitability

18. Treat the risk efficiently

19. Value-added activities

20. Roles and responsibilities towards risk

A convenient sampling method was used in the study to collect the data. 146 completely filled-in questionnaires were collected from 75 manufacturing units out of the entire Public Establishment database. The data was tabulated, compiled. The robustness was tested along with the ranking tests and the factor analysis using SPSS and AMOS. Bartlett's test of sphericity and Kaiser-Meyer-Olkin test were also undertaken to carry out factor analysis.

From the test of reliability, the Cronbach alpha score was observed to be 0.81 which shows the data qualifies (Nunnally, 1960).

\section{Findings}

Table 2 Demographic Profile

\begin{tabular}{|c|c|c|c|}
\hline & Category & Freq. & Percentage \\
\hline \multirow{2}{*}{ Sex } & Men & 83 & 56.8 \\
\hline & Women & 63 & 43.2 \\
\hline \multirow{5}{*}{ Age } & $18-25$ years & 13 & 8.9 \\
\hline & $>25-35$ years & 88 & 60.3 \\
\hline & $>36-45$ years & 40 & 27.4 \\
\hline & $>46-55$ years & 4 & 2.7 \\
\hline & $>$ Over 55 years & 1 & 0.7 \\
\hline \multirow{4}{*}{$\begin{array}{l}\text { Official } \\
\text { Position }\end{array}$} & Top Management & 21 & 14.4 \\
\hline & Managerial & 16 & 11.0 \\
\hline & Supervisory & 39 & 26.7 \\
\hline & Technical & 70 & 47.9 \\
\hline \multirow{5}{*}{$\begin{array}{l}\text { In the present } \\
\text { cadre for }\end{array}$} & $0-5$ years & 75 & 51.4 \\
\hline & Over $5-10$ years & 45 & 30.8 \\
\hline & Over $10-15$ years & 15 & 10.3 \\
\hline & Over $15-20$ years & 9 & 6.2 \\
\hline & Over $20-25$ years & 2 & 1.4 \\
\hline \multirow{9}{*}{ Department } & Commercial & 23 & 15.8 \\
\hline & Quality Control & 12 & 8.2 \\
\hline & Production (mfg.) & 26 & 17.8 \\
\hline & Logistics & 7 & 4.8 \\
\hline & $\begin{array}{l}\text { Finance and } \\
\text { Accounts }\end{array}$ & 14 & 9.6 \\
\hline & Marketing & 6 & 4.1 \\
\hline & Sales & 4 & 2.7 \\
\hline & Regulatory Control & 1 & 0.7 \\
\hline & Others/ Misc. & 53 & 36.3 \\
\hline \multirow{5}{*}{$\begin{array}{l}\text { Total number } \\
\text { of } \\
\text { employees }\end{array}$} & $0-100$ & 39 & 26.7 \\
\hline & $101-300$ & 25 & 17.1 \\
\hline & $301-500$ & 18 & 12.3 \\
\hline & $501-1000$ & 29 & 19.9 \\
\hline & $>1000$ & 35 & 24.0 \\
\hline
\end{tabular}


Table 3 CI Practices and Critical Success Factors

\begin{tabular}{|c|c|c|c|}
\hline \multirow{7}{*}{$\begin{array}{l}\text { Critical } \\
\text { Success Factors } \\
\text { used by the } \\
\text { companies }\end{array}$} & VM only & 6 & 4.1 \\
\hline & EE only & 6 & 4.1 \\
\hline & RM only & 28 & 19.2 \\
\hline & Lea only & 19 & 13.0 \\
\hline & EE \& Lea & 14 & 9.6 \\
\hline & VM, RM \& Lea & 6 & 4.1 \\
\hline & VM, EE, RM \& Lea & 67 & 45.9 \\
\hline \multirow{7}{*}{$\begin{array}{l}\text { Duration of the } \\
\text { use of CI tools } \\
\text { and techniques }\end{array}$} & $0-5$ years & 60 & 41.1 \\
\hline & Over $5-10$ years & 45 & 30.8 \\
\hline & Over $10-15$ years & 26 & 17.8 \\
\hline & Over $15-20$ years & 7 & 4.8 \\
\hline & Over $20-25$ years & 1 & 0.7 \\
\hline & Over 25 years & 1 & 0.7 \\
\hline & Never used CIs & 6 & 4.1 \\
\hline \multirow[t]{3}{*}{ CIs initiative } & Site related & 50 & 34.2 \\
\hline & Corporate related & 82 & 56.2 \\
\hline & No specific initiative & 14 & 9.6 \\
\hline \multirow{3}{*}{ Average Sales } & Hiked & 98 & 67.1 \\
\hline & Remains same & 37 & 25.4 \\
\hline & Dropped & 11 & 7.5 \\
\hline \multirow{3}{*}{$\begin{array}{l}\text { Average Cycle } \\
\text { time }\end{array}$} & Minimized & 85 & 58.2 \\
\hline & Increased & 27 & 18.5 \\
\hline & No change & 34 & 23.3 \\
\hline \multirow{3}{*}{$\begin{array}{l}\text { Products } \\
\text { Recalled }\end{array}$} & Some of them recalled & 67 & 45.9 \\
\hline & None & 48 & 32.9 \\
\hline & N.A. & 31 & 21.2 \\
\hline \multirow{11}{*}{$\begin{array}{l}\text { Type of } \\
\text { Products }\end{array}$} & Metals/Ore & 11 & 7.7 \\
\hline & Construction Materials & 13 & 9.0 \\
\hline & Tiles \& Marbles & 2 & 1.4 \\
\hline & Chemical compounds & 6 & 4.2 \\
\hline & Electricals & 4 & 2.8 \\
\hline & Oil \& Gas & 38 & 26.6 \\
\hline & Food \& Beverages & 3 & 2.1 \\
\hline & Stationery related & 1 & 0.7 \\
\hline & Plastics & 1 & 0.7 \\
\hline & Glasses & 2 & 1.4 \\
\hline & Others & 65 & 43.4 \\
\hline
\end{tabular}

It can be seen from Table 2 that the samples cover all kinds of demographics whereas CI practices and CSF details were shown in Table 3. It is also noted that some of the questions had multiple responses.

From Table 3, the following observations were made:

$67.1 \%$ of respondents reported that the sales got improved whereas $25.4 \%$ claimed that their sales figures remain the same. $7.5 \%$ of respondents found to report that their sales got dropped during the reported period.

$58.2 \%$ of respondents reported that the cycle time got minimized and $18.5 \%$ reported it got increased while $23.3 \%$ said that there is no change in average cycle time.

$45.9 \%$ respondents reported of recalling a few of their products while $32.9 \%$ of respondents reported that none of their products were recalled and $21.2 \%$ kept silent. 
Factor analysis and regression analysis were used to predict company savings from CI practices. $35.6 \%$ of respondents reported that their company bagged more than 10,000 Rials annual savings through continuous improvement. $32.4 \%$ reported that their company got less than 10,000 rials savings. $21.9 \%$ reported savings of more than 10,000 Rials and less than 25,000 Rials whereas $11 \%$ reported savings of more than 50,000 Rials.

Table 3 KMO and Bartlett's Test

\begin{tabular}{|rr|r|}
\hline Kaiser-Meyer-Olkin Measure of Sampling Adequacy & .942 \\
Bartlett's Test of Sphericity & Approx. Chi-Square & 2879.390 \\
& & 190 \\
Sig. & .000 \\
\hline
\end{tabular}

The p-value is less than 0.05 . So the null hypothesis gets rejected. Hence the factor analysis is valid. Further, the KMO coefficient $(0.942)$ is more than 0.5 , which shows that variables are exactly suitable for Factor analysis.

\section{Principal Component Analysis - Stage I}

Though 20 variables could be extracted, only those factors were extracted whose eigenvalue was more than 1.

Table 4 Total Variance Explained

\begin{tabular}{|c|c|c|c|c|c|c|c|c|c|}
\hline \multirow{2}{*}{ 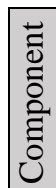 } & \multicolumn{3}{|c|}{ Initial Eigenvalues } & \multicolumn{3}{|c|}{$\begin{array}{l}\text { Extraction Sums of } \\
\text { Squared Loadings }\end{array}$} & \multicolumn{3}{|c|}{$\begin{array}{l}\text { Rotation Sums of Squared } \\
\text { Loadings }\end{array}$} \\
\hline & Total & $\begin{array}{l}\text { Var } \\
\%\end{array}$ & $\begin{array}{c}\text { Cum } \\
\%\end{array}$ & Total & $\begin{array}{c}\text { Var } \\
\%\end{array}$ & Cum & Total & $\begin{array}{c}\text { Var } \\
\%\end{array}$ & Cum \\
\hline 1 & 12.798 & 63.991 & 63.991 & 12.798 & 63.991 & 63.991 & 8.110 & 40.550 & 40.550 \\
\hline 2 & 1.316 & 6.580 & 70.571 & 1.316 & 6.580 & 70.571 & 6.004 & 30.021 & 70.571 \\
\hline 3 & .943 & 4.713 & 75.284 & & & & & & \\
\hline 4 & .680 & 3.400 & 78.685 & & & & & & \\
\hline 5 & .519 & 2.593 & 81.278 & & & & & & \\
\hline 6 & .482 & 2.410 & 83.688 & & & & & & \\
\hline 7 & .449 & 2.244 & 85.932 & & & & & & \\
\hline 8 & .401 & 2.005 & 87.937 & & & & & & \\
\hline 9 & .338 & 1.691 & 89.628 & & & & & & \\
\hline 10 & .321 & 1.607 & 91.235 & & & & & & \\
\hline 11 & .257 & 1.283 & 92.518 & & & & & & \\
\hline 12 & .243 & 1.217 & 93.735 & & & & & & \\
\hline 13 & .219 & 1.093 & 94.828 & & & & & & \\
\hline 14 & .209 & 1.045 & 95.874 & & & & & & \\
\hline 15 & .188 & .939 & 96.812 & & & & & & \\
\hline 16 & .163 & .816 & 97.628 & & & & & & \\
\hline 17 & .151 & .755 & 98.383 & & & & & & \\
\hline 18 & .130 & .651 & 99.034 & & & & & & \\
\hline 19 & .118 & .591 & 99.625 & & & & & & \\
\hline 20 & .075 & .375 & 100.000 & & & & & & \\
\hline
\end{tabular}

Extraction Method: Principal Component Analysis

The variables with an eigenvalue greater than one were retained as $40.55 \%$ of the variance was explained by factor 1 and $30.02 \%$ of the variance was explained by factor 2 and the two factors together show a cumulative variance explanation of $70.57 \%$.

\section{Stage II}

In stage II varimax rotation method was used. The factor matrix gives the loading of each variable to each factor. Table 5 shows the rotated factor loadings of the factors. All the 20 CSFs have been reduced to two factors, viz. F1 and F2. These two factors were:

F1 - Continuous Improvement Culture

F2 - Performance measurement and review 
Table 5 Rotated Component Matrix

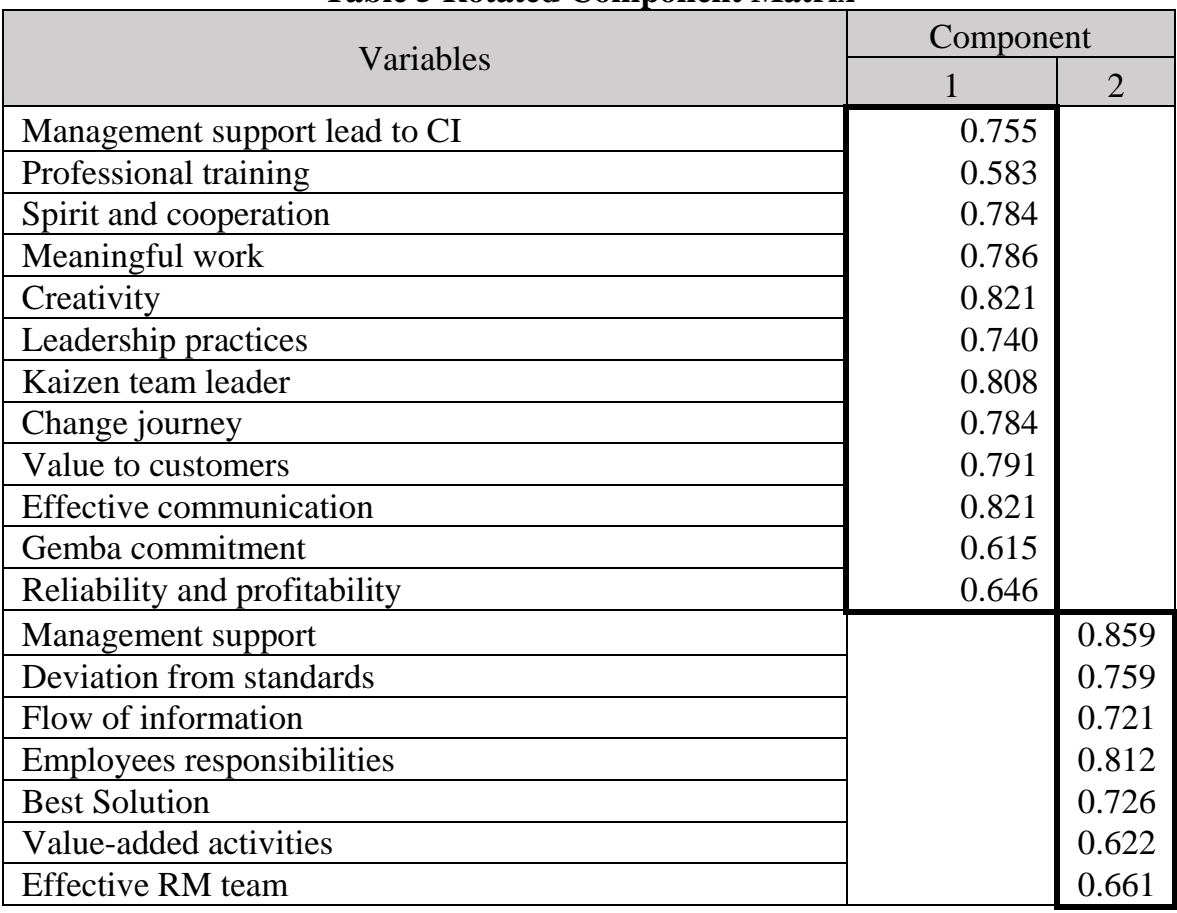

Extraction Method: Principal Component Analysis

Rotation Method: Varimax with Kaiser Normalization

${ }^{\text {a}}$ Rotation converged in 3 iterations

Table 6 Continuous Improvement Culture (F1)

\begin{tabular}{|c|c|c|c|c|}
\hline$\#$ & Variables & $\begin{array}{l}\text { Factor } \\
\text { loading }\end{array}$ & $\begin{array}{l}\text { Eigen } \\
\text { value } \\
\end{array}$ & $\begin{array}{c}\text { Percentage } \\
\text { Variance } \\
\end{array}$ \\
\hline 1 & Management support lead to CI & 0.755 & \multirow{12}{*}{8.110} & \multirow{12}{*}{40.550} \\
\hline 2 & Professional training & 0.583 & & \\
\hline 3 & Spirit and cooperation & 0.784 & & \\
\hline 4 & Meaningful work & 0.786 & & \\
\hline 5 & Creativity & 0.821 & & \\
\hline 6 & Leadership practices & 0.740 & & \\
\hline 7 & Kaizen team leader & 0.808 & & \\
\hline 8 & Change journey & 0.784 & & \\
\hline 9 & Value to customers & 0.791 & & \\
\hline 10 & Effective communication & 0.821 & & \\
\hline 11 & Gemba commitment & 0.615 & & \\
\hline 12 & Reliability and profitability & 0.646 & & \\
\hline
\end{tabular}

Table 7 Performance Measurement and Review (F2)

\begin{tabular}{|c|l|c|c|c|}
\hline Sno & \multicolumn{1}{|c|}{ Variables } & $\begin{array}{c}\text { Factor } \\
\text { loading }\end{array}$ & Eigenvalue & $\begin{array}{c}\text { Variance } \\
\%\end{array}$ \\
\hline 1 & Management support & 0.859 & & \\
\cline { 1 - 2 } 2 & Deviation from standards & 0.759 & & \\
\hline 3 & Flow of information & 0.721 & \multirow{2}{*}{$\mathbf{6 . 0 0 4}$} & \multirow{2}{*}{$\mathbf{7 0 . 5 7 1}$} \\
\cline { 1 - 2 } 4 & Employees responsibilities & 0.812 & & \\
\hline 5 & Best Solution & 0.726 & & \\
\hline 6 & Value-added activities & 0.622 & & \\
\hline 7 & Effective RM team & 0.661 & & \\
\hline
\end{tabular}


Regression score derived from factor analysis

After the factor analysis, a model to predict the company savings from continuous improvement practices was derived by using regression analysis as shown in Table 8 . The obtained factor scores for the above two composite factors were used in the following multivariate analysis of multiple regression.

\section{Model Fit}

Table 8 Regression Analysis Model Summary

\begin{tabular}{|c|c|c|c|c|}
\hline Model & $\mathrm{R}$ & $\mathrm{R}^{2}$ & $\begin{array}{c}\text { Adjusted } \\
\mathrm{R}^{2}\end{array}$ & $\begin{array}{c}\text { Std. Error of } \\
\text { the Estimate }\end{array}$ \\
\hline 1 & $.899^{\mathrm{a}}$ & .808 & .805 & .56658 \\
\hline
\end{tabular}

a Predictors: (Constant), Performance Measurement Review,

Continuous Improvement Culture.

The overall variance was explained by $80.9 \%$ i.e., the correlation between the independent and dependent variables seemed to be high.

${ }^{a}$ Dependent Variable: Company Savings

bPredictors: (Constant), Performance Measurement Review,

Continuous Improvement Culture

From the ANOVA table, it was checked that the p-value $<.05$, which indicated that the model was acceptable. Coefficients $^{\mathrm{a}}$

\begin{tabular}{|l|l|l|r|r|r|}
\hline \multirow{2}{*}{ Model } & \multicolumn{2}{|c|}{$\begin{array}{c}\text { Unstandardized } \\
\text { Coefficients }\end{array}$} & $\begin{array}{l}\text { Standardized } \\
\text { Coefficients }\end{array}$ & \multirow{2}{*}{$\mathrm{t}$} & \multirow{2}{*}{ Sig. } \\
\cline { 2 - 5 } & \multicolumn{1}{|c|}{$\mathrm{B}$} & $\begin{array}{c}\text { Std. } \\
\text { Error }\end{array}$ & Beta & & \\
\hline (Constant) & 2.781 & .047 & & & \\
Continous Improvement Culture & 1.054 & .047 & .821 & 22.391 & .000 \\
Performance Measurement Review & .471 & .047 & .367 & 10.006 & .000 \\
\hline
\end{tabular}

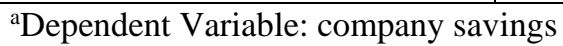

'Continuous improvement culture' $(\mathrm{F} 1, \beta=0.821, \mathrm{p}=0.000)$ and 'Performance Measurement and Review' (F2 $\beta=0.367, p=0.000$ ), were significant at the 0.05 level and positively related to Company Savings. Based on the unstandardized B value, the obtained regression equation was given as:

\section{Company Savings $=2.781+1.054 *$ Continuous improvement culture $+0.471 *$ Performance}

\section{measurement and review}

Continuous Improvement Culture holds the highest standardized coefficients (8.21), which means this Continuous Improvement Culture is the most important factor associated with Company Savings.

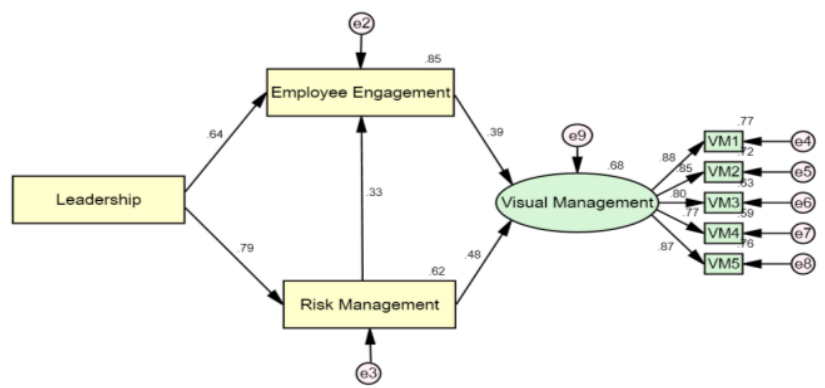

Figure 2 Successful Practices and Strategies of Continuous Improvement (CI)

This structural equation model explores the relationship between Employee Engagement, Leadership, Risk Management, and Visual Management over the successful practices and Strategies of Continuous Improvement (CI). 
Table 9 Model Fit Indices

\begin{tabular}{|l|c|}
\hline \multicolumn{1}{|c|}{ Index } & \\
\hline Sig. (P value) & .074 \\
\hline CMIN/DF & 1.758 \\
\hline Goodness of Fit Index (GFI) & .955 \\
\hline Adjusted Goodness of Fit Index (AGFI) & .910 \\
\hline Normed Fit Index (NFI) & .972 \\
\hline Comparative Fit Index (CFI) & .987 \\
\hline Root Mean Square Error of Approximation (RMSEA) & .042 \\
\hline
\end{tabular}

The model fit is non-significant as the p-value $=.074>.05$ which indicates that the model fits perfectly. Further, CMIN/DF value is also 1.758 which accepts the model fit. The goodness of fit index is the proportion of variance for estimating population covariance is $0.955>.95$ which indicates the good model fit. Also, the AGFI value is $.910>0.90$ which approves the good model fit. Moreover, the NFI value is $0.972>0.95$ which also confirms that the model is a good model fit. CFI value is $.987>0.90$ which describes that this model as a good model of fit (Hu and Bentler, 1999). The RMSEA lies between 0 and 1 and RMSEA $<.06$, which indicates a better model of fit (Brown and Cudeck, 1993).

Table 10 Regression Weights

\begin{tabular}{|lll|cccc|}
\hline & & & Estimate & S.E. & C.R. & P \\
\hline Risk Management & $<---$ & Leadership & .704 & .046 & 15.446 & $* * *$ \\
Employee Engagement & $<---$ & Leadership & .640 & .052 & 12.205 & $* * *$ \\
Employee Engagement & $<---$ & Risk Management & .372 & .059 & 6.359 & $* * *$ \\
Visual Management & $<---$ & Risk Management & .105 & .021 & 4.997 & $* * *$ \\
Visual Management & $<---$ & Employee Engagement & .076 & .019 & 4.099 & $* * *$ \\
VM1 & $<---$ & Visual Management & 1.000 & & & \\
VM2 & $<---$ & Visual Management & .882 & .064 & 13.853 & $* * *$ \\
VM3 & $<---$ & Visual Management & .851 & .069 & 12.351 & $* * *$ \\
VM4 & $<---$ & Visual Management & .810 & .070 & 11.593 & $* * *$ \\
VM5 & $<---$ & Visual Management & .939 & .064 & 14.580 & $* * *$ \\
\hline
\end{tabular}

From Table 11, it can be seen that the unconstrained estimates of all items are significant at .001 level which explains that Leadership Influences Risk Management and Employee Engagement at .001 level. Risk Management Influences Employee Engagement and Visual Management at .001 level. Employee Engagement influences Visual Management at .001 level. Each unstandardized regression coefficient represents the amount of change in the dependent or mediating variable for each one-unit change in the variable predicting it.

Table 11 Standardized Regression Weights

\begin{tabular}{|lcl|c|}
\hline \multicolumn{3}{|c|}{} & Estimate \\
\hline Risk Management & $<---$ & Leadership & .786 \\
Employee Engagement & $<---$ & Leadership & .636 \\
Employee Engagement & $<---$ & Risk Management & .331 \\
Visual Management & $<---$ & Risk Management & .476 \\
Visual Management & $<---$ & Employee Engagement & .388 \\
VM1 & $<---$ & Visual Management & .877 \\
VM2 & $<---$ & Visual Management & .848 \\
VM3 & $<---$ & Visual Management & .796 \\
VM4 & $<---$ & Visual Management & .766 \\
VM5 & $<---$ & Visual Management & .871 \\
\hline
\end{tabular}

It shows the correlation between the factors measured and the observed variables. It also indicates that VM1, VM2, VM3, VM4, and VM5 are reliable indicators of the variable Visual Management; Leadership is the reliable indicator for Risk Management and Employee Engagement; Risk Management is the reliable indicator for Visual Management and Employee Engagement; Employee Engagement is the reliable indicator 
for Visual Management. With all the positive coefficient measures it is confirmed that in this model all the paths have a good model fit.

Table 12 Squared Multiple Correlations

\begin{tabular}{|l|c|}
\hline & Estimate \\
\hline Risk Management & .617 \\
Employee Engagement & .846 \\
Visual Management & .684 \\
VM5 & .758 \\
VM4 & .587 \\
VM3 & .633 \\
VM2 & .719 \\
VM1 & .770 \\
\hline
\end{tabular}

\section{Conclusion}

It is identified that all the considered CSFs influenced the management decision towards the implementation of continuous improvement in the companies. These CSFs were acknowledged by the manufacturing companies in Oman, which confirms that CI tools are essential elements of business strategy within this sector. Organizations that incorporate CI into their production, and the related quality control systems will have a competitive edge.

Numerous market advantages have been identified (such as reduction in the cost of products sold and cycle time, etc.) in several manufacturing industries. Thus, the results reveal that the Omani manufacturing companies using structured CI programs had lesser product recalls, leading to increased overall sales, decrease in processing time. Further, it is also revealed that the CI culture and Employee Performance Measurement and Review are instrumental in translating into company savings. The overall sales raised, while the average processing time had declined.

\section{Acknowledgment}

This paper is the outcome of the research carried out with the funding from The Research Council, Oman (TRC) - Ministry of Higher Education Research \& Innovation of the Sultanate of Oman under the Block Funding Program vide No. TRC/BFP/SHCT/01/2019.

\section{References}

1. Adalı, E. A., \& Işık, A. T. (2017). The Multi-Objective Decision-Making Methods Based on MULTIMOORA and MOOSRA for the laptop selection problem. Journal of Industrial Engineering International, 13(2), 229-237.

2. Ahmad, E. M. M. A. (2018). Theoretical framework development for supply chain risk management for Malaysian manufacturing. Int. J Sup. Chain. Mgt.,7(6), 325.

3. Alefari, M., Salonitis, K., \& Xu, Y. (2017). The role of leadership in implementing lean manufacturing. Procedia CIRP, 63, 756-761. https://doi.org/10.1016/j.procir.2017.03.169

4. Aleu, F. G., \& Van Aken, E. M. (2016). Systematic literature review of critical success factors for continuous improvement projects. International Journal of Lean Six Sigma, 7(3), 214232. https://doi.org/10.1108/IJLSS-06-2015-0025

5. Al-Qayoudhi, S.A.S., Hussaini, S.S., \& Khan, F.R. (2017). Application of Total Quality Management (TQM) in Higher Education Institution (HEI) in Oman: Shinas College of Technology - A Case Study, Humanities \& Social Sciences Reviews, 5(1), 21-32. https://doi.org/10.18510/hssr.2017.512

6. Al-Qayoudhi, S.A.S., Pria, S. \& Prasad, V. V. (2021). Continuous Improvement Practices in Manufacturing Companies in the Sultanate of Oman, International Journal of Research in Entrepreneurship \& Business Studies, 2(3), 1-14. https://doi.org/10.47259/ijrebs.231

7. Anand, G., Ward, P. T., Tatikonda, M. V. \& Schilling, D. A. (2009). Dynamic Capabilities through Continuous Improvement Infrastructure. Journal of Operations Management, 27(6), 444-461. https://doi.org/10.1016/j.jom.2009.02.002

8. Bakator, M., Borić, S., \& Petrović, N. (2018). Differences and Similarities between Total Quality Management, ISO 9001, Lean production, and Six SIGMA. International Journal Advanced Quality, 46(1), 17-20.

9. Brown, M. W., \& Cudeck, R. (1992). Alternative Ways of Assessing Model Fit. Sociological Methods and Research, 21(2), 230-258.

10.Dombrowski, U., \& Mielke, T. (2013). Lean leadership-fundamental principles and their application. Procedia CIRP, 7, 569-574. https://doi.org/10.1016/j.procir.2013.06.034 
11. Fadzil, N. S., Noor, N. M., \& Rahman, I. A. (2017, November). Need of risk management practice amongst Bumiputera contractors in Malaysia construction industries. In IOP Conference Series: Materials Science and Engineering, 271(1), 012035. IOP Publishing.

12. Ferede, Y. S., Mashwama, N. X., \& Thwala, W. D. (2021). Strategies to Improve Risk Management In Construction Industries. Proceedings of International Structural Engineering and Construction, 8, 1. https://10.14455/ISEC.2021.8(1).RAD-10

13. Galli, B. J. (2018). Continuous Improvement Relationship to Risk Management: The Relationship Between them. International Journal of Applied Management Sciences and Engineering, 5(2), 1 -14. http://doi.org/10.4018/IJAMSE.2018070101

14. Glover, W. J., Farris, J. A., \& Van Aken, E. M. (2015). The Relationship Between Continuous Improvement and Rapid Improvement Sustainability. International Journal of Production Research, 53(13), 4068 - 4086. https://doi.org/10.1080/00207543.2014.991841

15. Haddas, M. A., Asiri, M. H., Mukhalid, R. F., Alahmari, S. S., Al-Qathtani, S. A. \& Hasan, S. H. (2014). Continuous Improvement a [euro] Development with Time. International Journal of Computer Applications, 108(8), 35-39.

16. Ghuman, K. (2016). A prognostic examination of functional and emotional employee engagement drivers and their impact on employee performance. FIIB Business Review, 5(2), 78-87. https://doi.org/10.1177/2455265820160209

17. Hambach, J., Kümmel, K., \& Metternich, J. (2017). Development of a Digital Continuous Improvement System for Production. Procedia CIRP, 63, 330-335. https://doi.org/10.1016/j.procir.2017.03.086

18.Hu, L. T., \& Bentler, P. M. (1999). Cut-off criteria for Fit Indexes in Covariance Structure Analysis: Conventional Criteria Versus New Alternatives. Structural Equation Modeling: A Multidisciplinary Journal, 6(1), 1-55. https://doi.org/10.1080/10705519909540118

19. Improta, G., Romano, M., Di Cicco, M. V., Ferraro, A., Borrelli, A., Verdoliva, C., ... \& Cesarelli, M. (2018). Lean thinking to improve emergency department throughput at AORN Cardarelli hospital. BMC Health Services Research, 18(1), 1-9. https://doi.org/10.1186/s12913-018-3654-0

20.Jaca, C., Viles, E., Jurburg, D., \& Tanco, M. (2014). Do companies with greater deployment of participation systems use Visual Management more extensively? An exploratory study. International Journal of Production Research, 52(6), 1755-1770. https://doi.org/10.1080/00207543.2013.848482

21.Jurburg, D., Viles, E., Tanco, M., \& Mateo, R. (2017). What motivates employees to participate in continuous improvement activities? Total Quality Management \& Business Excellence, 28 (13-14), 14691488. https://doi.org/10.1080/14783363.2016.1150170

22. Karami, M., Samimi, A., \& Jafari, M. (2020). The necessity of risk management evaluations in petrochemical industries. Advanced Journal of Chemistry-Section B,2(3), 151-158. https://dx.doi.org/10.22034/ajcb.2020.109731

23. Kurpjuweit, S., Reinerth, D., Schmidt, C. G., \& Wagner, S. M. (2019). Implementing visual management for continuous improvement: barriers, success factors, and best practices. International Journal of Production Research, 57(17), 5574-5588. https://doi.org/10.1080/00207543.2018.1553315

24. Madan, P., \& Srivastava, S. (2015). Employee engagement, job satisfaction, and demographic relationship: An empirical study of private sector bank managers. FIIB Business Review, 4(2), 53-62. https://doi.org/10.1177\%2F2455265820150210

25. Maletič, D., Maletič, M., \& Gomišček, B. (2012). The relationship between continuous improvement and maintenance performance. Journal of Quality in Maintenance Engineering. https://doi.org/10.1108/13552511211226175

26. Nunnally, J. (1960). The place of statistics in psychology. Educational and Psychological Measurement, 20(4), 641-650. https://doi.org/10.1177\%2F001316446002000401

27. Oman Observer (16 ${ }^{\text {th }}$ Dec. 2020). Vision 2040 to Improve Oman's Global Standings. Oman Observer. http://www.omanobserver.om/article/6459/1/vision-2040-to-improve-omans-global-standings

28. Singh, N., \& Singh, S. B. (2017). A modified mean gray wolf optimization approach for benchmark and biomedical problems. Evolutionary $\quad$ Bioinformatics, 13, 1176934317729413. https://doi.org/10.1177\%2F1176934317729413

29. Salonitis, K., \& Tsinopoulos, C. (2016). Drivers and Barriers of Lean Implementation in the Greek Manufacturing Sector. Procedia CIRP, 57, 189-194. https://doi.org/10.1016/j.procir.2016.11.033

30. Weerasooriyan, N. W. M. R., \& Alwis, A. C. D. (2017). Impact of Employee Engagement on Lean Manufacturing: An Empirical Study in Sri Lanka. FIIB Business Review, 6(2), 33-42. https://doi.org/10.1177\%2F2455265820170206

31. Womack, J. P., \& Jones, D. T. (2017). Lean thinking. Come Creare Valore e Bandire Gli Sprechi. Goware \& Guerini Next: Milano. 